\title{
Studies on L-Threonine Fermentation
}

\section{Part I. Production of L-Threonine by Auxotrophic Mutants of Various Bacteria}

\author{
By Hiroshi Kase, Haruo TANaKa and Kiyoshi NaKayama \\ Tokyo Research Laboratory, Kyowa Hakko Kogyo Co., Ltd., \\ Machida-shi, Tokyo \\ Received July 2, 1971
}

\begin{abstract}
Fifteen strains of bacteria were treated with ultraviolet light or N-methyl-N'-nitro-Nnitrosoguanidine to derive auxotrophic mutants, which were screened for their ability to produce L-threonine. A number of auxotrophs were derived from each strain. Among them, those which produced a large amount of L-threonine were found in Aerobacter aerogenes, Serratia marcescens and Escherichia coli, the members of the family Enterobacteriaceae. Nutritional requirements of these threonine producers were proved to be methionine, lysine, or $\alpha, \xi^{*}$ diaminopimelic acid (DAP).

In $A$. aerogenes and $E$. coli, double and triple auxotrophs were derived with futher mutational treatment. As a rule, imposition of additional block led to the increase of L-threonine production. In E. coli, many triple auxotrophs (DAP-, $\mathrm{Met}^{-}$, $\mathrm{Ile}^{-}$) and their isoleucine revertants were screened for their ability to produce L-threonine. Enhancement of L-threonine production was achieved with these mutants.

One of the isoleucine revertants, KY8280, was used to investigate some cultural conditions. As a result, L-threonine accumulation reached to a level of $13.8 \mathrm{mg} / \mathrm{ml}$ with the medium containing $7.5 \circ \mathrm{g}$ fructose.
\end{abstract}

Studies of L-threonine production by direct fermentation have progressed along two lines with respect to the kind of microbial mutants, i.e. auxotrophic mutants and analog-resistant mutants. There have been several reports as for L-threonine production by the use of auxotrophic mutants. ${ }^{1 \sim 7}$ However, the yields

1) H. T. Huang Appl. Microbiol., 9, 419 (1962).

2) Y. Sugawara, T. Nozaki and S. Nishimura, Amino Acid and Nucleic Acid, 10, 68 (1964).

3) H. Watanabe, N. Sato, S. Kinoshita and K. Nakayama, Japanes Patent, 38-14395 (1963).

4) K. Watanabe and K. Hirokawa, Japanese Patent, 43-11752 (1968).

5) B. J. Abbott and P. Gerhardt, Biotech. Bioeng., 12, 603 (1970).

6) Y. Tsukada and T. Sugimori, Agr. Biol. Chem., 35, I (1971).

7) K. Takayama, S. Abe and S. Kinoshita, Amino Acid and Nucleic Acid, 19, 121 (1969). by these mutants were not so good except an isoleucine auxotroph ${ }^{7}$ of Arthrobacter parafineus, a hydrocarbon utilizing bacterium, which produced a large amount of L-threonine and $L$-valine from $n$-paraffin. Recently, attempts have been made, with success, for L-threonine production with threonine analog $(\alpha$-amino- $\beta$ hydroxyvaleric acid)-resistant mutants of Brevibacterium flavum reported by I. Shiio et al. ${ }^{8,91}$ and Proteus rettgeri reported by T. Nakamura et $a$. $^{101}$

The present investigation was undertaken

8) I. Shiio and S. Nakamori, Agr. Biol. Chem., 33, 1152 (1969).

9) I. Shiio and S. Nakamori, ibid., 34, 448 (1970).

10) T. Nakamura and H. Aida, Abstracts of Papers, Annual Meeting of Nippon Nogei Kagaku Kai, Fukuoka, Kyushu, April, 1970, p. 4. 
in order to select a good threonine producer among auxotrophic mutants from various bacteria. Fifteen strains of bacteria representing seven families were mutagenized, and the auxotrophs obtained were investigated for their ability to produce L-threonine. Thus, it has been found that L-threonine productivity seemed to be closely related to the nutritional requirement and to the taxonomical position to which an auxotroph belongs.

Among the tested strains, an E. coli auxotroph which produced a large amount of Lthreonine was used to investigate the cultural conditions for L-threonine production to some extent.

\section{MATERIALS AND METHODS}

Microorganisms. Fifteen strains of bacteria presented in Table I were subjected to mutational treatment. The selection of auxotrophs was limited mainly to those which require amino acid or amino acids directly related to $\mathrm{L}$-threonine biosynthesis, i.e., methinone, isoleucine, lysine and $\alpha$, $\varepsilon$-diaminopimelic acid (DAP).

Culture medium. Ninimal and complete medium

Table I. ORganisms Used

\begin{tabular}{|c|c|c|}
\hline Family & Species & Strain No. \\
\hline \multirow[t]{2}{*}{ Pseudomonadaceae } & Pseudomonas fluorescens & ATCC 15453 \\
\hline & Aeromonas formicans & ATCC 13137 \\
\hline Azotobacteraceae & Azotobacter vinelandii & ATCC 9046 \\
\hline Rhizobiaceae & Rhizobium trifolii & ATCG 10140 \\
\hline \multirow[t]{3}{*}{ Enterobacteriaceae } & Escherichia coli W & АТCC 9637 \\
\hline & Aerobacter aerogenes & ATCC 8308 \\
\hline & Serratia marcescens & ATCG 19180 \\
\hline \multirow[t]{5}{*}{ Corynebacteriaceae } & $\begin{array}{l}\text { Corynebacterium } \\
\text { glutamicum }\end{array}$ & ATCC 13032 \\
\hline & C. fascians & ATCC 12975 \\
\hline & $\begin{array}{l}\text { Arthrobacter } \\
\quad \text { ureafaciens }\end{array}$ & ATCC 7562 \\
\hline & A. globiformis & ATCC 8010 \\
\hline & Microbacterium lacticum & ATCC 8180 \\
\hline \multirow[t]{2}{*}{ Bacillaceae } & Bacillus megaterium & ATCC 15450 \\
\hline & Bacillus sp. & KY 3965 \\
\hline Actinomycetaceae & Nacardia globerula & ATCC 13130 \\
\hline
\end{tabular}

of the following composition were used for mutation experiments. Minimal medium (per liter): $10 \mathrm{~g}$ glucose, $1 \mathrm{~g} \mathrm{NH}{ }_{4} \mathrm{H}_{2} \mathrm{PO}_{4}, 0.2 \mathrm{~g} \mathrm{KCl}, 0.2 \mathrm{~g} \mathrm{MgSO}_{4} \cdot 7 \mathrm{H}_{2} \mathrm{O}$, and I ml of trace element solution* $(\mathrm{pH} 7.2)$. $\quad * 88 \mathrm{mg}$ $\mathrm{Na}_{2} \mathrm{~B}_{4} \mathrm{O}_{7} \cdot 10 \mathrm{H}_{2} \mathrm{O}, 37 \mathrm{mg}\left(\mathrm{NH}_{4}\right)_{6} \mathrm{Mo}_{7} \mathrm{O}_{27} \cdot 4 \mathrm{H}_{2} \mathrm{O}, 8.8 \mathrm{mg}$ $\mathrm{ZnSO}_{4} \cdot 7 \mathrm{H}_{2} \mathrm{O}, 270 \mathrm{mg} \mathrm{CuSO}_{4} \cdot 5 \mathrm{H}_{2} \mathrm{O}, 7.2 \mathrm{mg} \mathrm{MnCl}_{2}$. $4 \mathrm{H}_{2} \mathrm{O}$ and $970 \mathrm{mg} \mathrm{FeCl}_{3} \cdot 6 \mathrm{H}_{2} \mathrm{O}$, in a liter of distrilled water. Complete medium (per liter); $10 \mathrm{~g}$ peptone, $10 \mathrm{~g}$ meat extract, $5 \mathrm{~g}$ yeast extract, $3 \mathrm{~g} \mathrm{NaCl}$ and $50 \mathrm{mg}$ meso-DAP ( $\mathrm{pH} 7.2)$.

Seed medium for threonine accumulation experiments was as follows; $2 \%$ glucose, $1 \%$ peptone, $1 \%$ yeast extract, $0.25 \%$ sodium chloride, and $50 \mu \mathrm{g} / \mathrm{ml}$ of meso$\mathrm{DAP}$ ( $\mathrm{pH}$ 7.4). Basal media for screening experiments are shown in Table II. Medium B was used for $E$. coli mutants and medium $\mathrm{A}$ for the other mutants.

TABLE II. Composition of Basal Media

\begin{tabular}{lll}
\hline & $\mathrm{A} \%$ & $\mathrm{~B} \%$ \\
\hline Glucose & 10.0 & \\
Glycerol & & 5.0 \\
$\left(\mathrm{NH}_{4}\right)_{2} \mathrm{SO}_{4}$ & 2.0 & 1.4 \\
$\mathrm{~K}_{2} \mathrm{HPO}_{4}$ & 0.05 & \\
$\mathrm{KH}_{2} \mathrm{PO}_{4}$ & 0.05 & 0.3 \\
$\mathrm{MgSO}_{4} \cdot 7 \mathrm{H}_{2} \mathrm{O}$ & 0.025 & 0.03 \\
$\mathrm{FeSO}_{4} \cdot 7 \mathrm{H}_{2} \mathrm{O}$ & 0.001 & \\
$\mathrm{MnSO}_{4} \cdot 4 \mathrm{H}_{2} \mathrm{O}$ & 0.001 & \\
$\mathrm{CaCO}$ & 2.0 & 2.0 \\
$\mathrm{pH}$ & 7.4 & 7.8 \\
\hline
\end{tabular}

Mutation. Mutations were induced by treatment of the bacterial cells with ultraviolet light (UV) or $\mathrm{N}$-methyl-N'-nitro-N-nitrosoguanidine (NTG) as following procedure.

UV treatment. The bacterial cells grown on a bouillon agar slant overnight were suspended in saline water. Five to seven milliliters of the cell suspension (ca. $10^{8} \sim 10^{9}$ cells $\left./ \mathrm{ml}\right)$ in Petri dish $(9 \mathrm{~cm}$ in diameter) were exposed to UV ( $15 \mathrm{~W}$ germicidal lamp) at the distance of $46 \mathrm{~cm}$.

NTG treatment. The bacterial cells grown on a bouillon agar slant overnight were suspended in TrisMaleate buffer ( $\mathrm{pH} 6.0$ ). Two $\mathrm{ml}$ of the suspension were mixed with equal volume of the buffer solution containing $100 \sim 800 \mu \mathrm{g} / \mathrm{ml}$ of NTG and incubated for $10 \sim 120 \mathrm{~min}$ at a room temperature.

Treated cells were washed and plated on a complete medium. Colonies grown in 2 or 3 days were tested by replica method, and those which grew on 
the minimal medium supplemented with methionine, isoleucine, lysine and DAP, but not on the minimal medium were selected as the desired auxotrophs. In some cases, penicilline enrichment method was applied according to the procedure of Davis, ${ }^{\text {II }}$ Lederberg and Zinder. ${ }^{121}$

Mixed culture mutation. When it was desired to obtain a certain type of auxotrophs from various bacteria, it is assumed that the frequency of appearance of the desired auxotrophs may be different among different groups of bacteria. For our purpose, it may be elegant to select bacteria having high frequencies of the desired mutation, and it is not efficient to waste time for obtaining a desired mutant from a bacterium having low frequency of the desired mutation. From these points of view, the method by which several strains are simultaneously mutagenized may be better to select the desired auxotrophs from various groups of bacteria. We devised a method suitable for such purpose and named it as "mixed culture mutation."

Cells of several strains grown on bouillon agar slants overnight were separately suspended in TrisMaleate buffer (ca. $10^{8} \mathrm{cells} / \mathrm{ml}$ ). The cell suspension was mixed each other in a suitable ratio, which treated with NTG as described above. After isolation of the desired auxotrophs, the species of each auxotroph was identified by colonial morphology and microscopic examination.

Culture method. Ten milliliters of a seed medium in a large test tube $(25 \mathrm{~mm} \times 19 \mathrm{~cm})$ was inoculated with one loopful of an organism grown on a boullon agar slant containing $50 \mu \mathrm{g} / \mathrm{ml}$ of meso-DAP, and incubated on a test tube shaker. After incubation for $24 \mathrm{hr}$ at $30^{\circ} \mathrm{C}, 1 \mathrm{ml}$ of this seed culture was transferred into a large test tube containing $10 \mathrm{ml}$ of a fermentation medium. The test tube was incubated at $30^{\circ} \mathrm{C}$ on a test tebe shaker for $72 \mathrm{hr}$.

Analysis. L-Threonine in the culture broth was assayed by ninhydrin method after separating by paper chromatography using the following solvent system; methylethylketone- $n$-butanol- conc. ammonia- water $(100: 100: 5: 60)$. For the estimation of growth in a fermentation medium containing calcium carbonate,

II) B. D. Davis, J. Am. Chem. Soc., 70, 4267 (1948). 12) J. Lederberg and N. Zinder, J. Am. Chem. Soc., 70, 4267 (1968).
$1 \mathrm{ml}$ of $6 \mathrm{~N} \mathrm{HCl}$ was added to $1 \mathrm{ml}$ aliquot of the broth to dissolve the calcium carbonate, and the optical density of the solution was measured after dilution $1: 10$, which was converted to dried cell weight (DCW) by appropriate calibration curve.

\section{RESULTS}

\section{Isolation of auxotrophic mutants by "mixed culture mutation",}

A number of the desired auxotrophs were derived from each strain by "mixed culture mutation" method. An example of the "mixed culture mutation" is shown in Table III and IV. Aerobacter aerogenes ATCG 8308, Serratia marcescens ATCC 19180, Pseudomonas fuorescens ATCC 15453 and Microbacterium lacticum ATCC

Table III. Auxotrophs OBTaINed by the Method of "Mixed Culture Mutation"

Four strains grown on bouillon agar slants overnight were separately suspended in Tris-Maleate buffer. The concentration of the cell suspension was $2.1 \times 10^{8}$ cells $/ \mathrm{ml}$ for $\mathrm{M}, 1.2 \times 10^{8}$ cells $/ \mathrm{ml}$ for $\mathrm{S}, 4.5 \times$ $10^{8}$ cells/ml for $\mathrm{P}$ and $1.1 \times 10^{8}$ cells $/ \mathrm{mL}$ for $\mathrm{A}$. Equal volume of each suspension was mixed, which treated with NTG under indicated conditions.

\begin{tabular}{|c|c|c|c|c|c|c|c|}
\hline \multicolumn{2}{|c|}{ NTG dose } & \multirow{2}{*}{$\begin{array}{l}\text { Colonies } \\
\text { tested }\end{array}$} & \multirow{2}{*}{$\begin{array}{l}\text { Auxotrophs } \\
\text { obtained }\end{array}$} & \multicolumn{4}{|c|}{ Species ${ }^{a l}$} \\
\hline $\mathrm{mg} / \mathrm{m}$ & $\min$ & & & $S$ & A & $\mathrm{P}$ & $\mathrm{M}$ \\
\hline 1 & 35 & 8,000 & 7 & 4 & 3 & 0 & 0 \\
\hline 2 & 35 & 10,154 & 26 & 3 & 20 & 3 & 0 \\
\hline \multirow[t]{2}{*}{4} & 35 & 4,300 & 3 & 0 & 3 & 0 & 0 \\
\hline & sum & 22,454 & 36 & 7 & 26 & 3 & 0 \\
\hline
\end{tabular}

a) S: Serratia marcescens A: Aerobacter aerogenes P: Pseudomonas fuorescens M: Microbacterium lacticum.

Table IV. Auxotrophs Obtained by the Method OF "Mixed Culture Mutation"

\begin{tabular}{|c|c|c|c|c|c|c|c|}
\hline \multirow[b]{2}{*}{ Species } & \multirow{2}{*}{$\begin{array}{c}\text { Auxotrophs } \\
\text { obtained }\end{array}$} & \multicolumn{6}{|c|}{ Requirement } \\
\hline & & DAP & Lys & $\begin{array}{l}\text { DAP/ } \\
\text { Lys }\end{array}$ & Met & Ile C & Others \\
\hline S. marcescens & 7 & 0 & 1 & 1 & 3 & 2 & 0 \\
\hline A. aerogenes & 26 & 3 & 1 & 0 & 19 & 1 & 2 \\
\hline P. fuorescens & 3 & 0 & 1 & 0 & 2 & 0 & 0 \\
\hline$M$. lacticum & 0 & 0 & 0 & 0 & 0 & 0 & 0 \\
\hline
\end{tabular}


8180 were employed in this experiment. Thirty-six auxotrophs in total were isolated from 22,454 colonies after NTG treatments under various conditions. Twenty-six of 36 auxotrophs were proved to be $A$. aerogenes, while no auxotrophs of $M$. lacticum was isolated in this experiment. The data of the nutritional requirement of these mutants shown in Table IV indicate that methionine auxotrophs were found to be readily isolated in each strain, while isoleucine, DAP or lysine auxotrophs seemed to have rather low frequency of appearance.

Thus, many auxotrophs were isolated in each strain and were screened for their ability to produce L-threonine. As a result, it was proved that the auxotrophs which produced an appreciable amount (above $1 \mathrm{mg} / \mathrm{ml}$ ) of $\mathrm{L}$ threonine belonged to $A$. aerogenes, $S$. marcescens and $E$. coli, the members of the family Enterobacteriaceae. The requirements of these threonine producers were found to be methionine, DAP, or lysine. On the other hand threonine accumulation was proved to be slight at best in other strains

Isolation of double auxotrophs of $A$. aerogenes

Attempts were made to isolate double auxotrophs of $A$. aerogenes. The results are shown in Fig. 1. Methionine or DAP auxotrophs, NM-4, NM-59 and NM-17 derived from $A$. aerogenes ATCC 8308 were found to produce about one milligram per milliliter of L-threo- nine. Many double auxotrophs were derived from them. Of the combination of nutritional requiremets, DAP (or lysine) plus methionine requirement gave the best result in L-threonine production. Thus, NM-4-05 (Met $^{-}, \mathrm{DAP}^{-} / \mathrm{Lys}^{-}$) produced $3.6 \mathrm{mg} / \mathrm{ml}$ of $\mathrm{L}$-threonine in the culture broth.

Isolation of double and triple auxotrophs of E. coli Double and triple auxotrophs were isolated in $E$. coli. On the basis of the results obtained in $A$. aerogenes, methionine and DAP auxotrophs were derived from $E$. coli W (ATCG 9637). Among them, KY8274 produced 2.0 $\mathrm{mg} / \mathrm{ml}$ of L-threonine.

From KY8274 ( $\mathrm{Met}^{-}$, $\mathrm{DAP}^{-}$), isolation of the mutants in which the third nutritional deficiency is L-isoleucine was achieved by use of penicillin enrichment technique after UV treatment, and nineteen desired auxotrophs were obtained from 9540 colonies tested. All triple auxotrophs were stable in their requirement for many generations, as far as they were transferred on agar slants of the minimal medium supplemented with only the required amino acids. On the other hand, 17 out of 19 strains were found to revert spontaneously with respect to isoleucine requirement when they were transferred for only two or three times on bouillon agar slants.

The triple auxotrophs and their revertants were screened for their ability to produce Lthreonine. Figure 2 shows their distribution

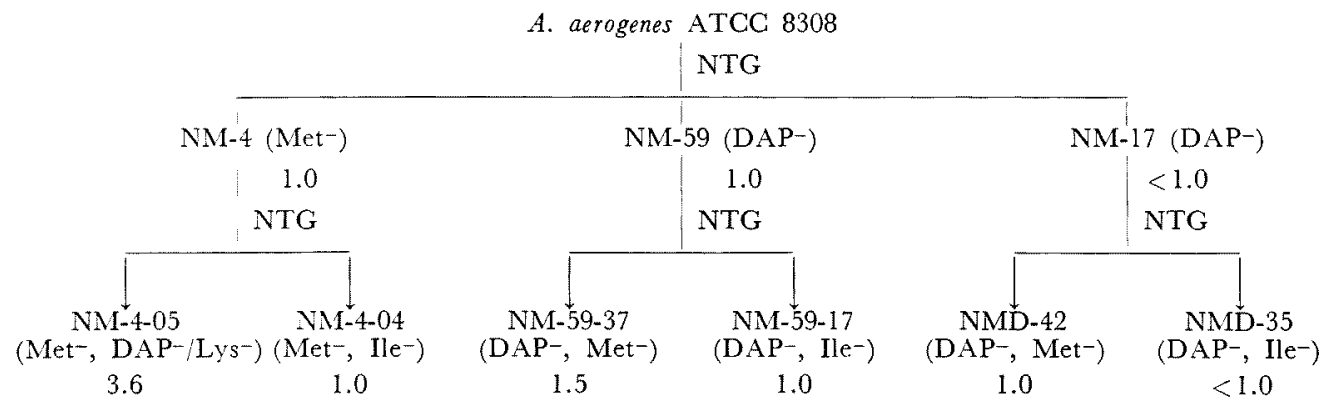

FIG. 1. Auxotrophs Derived from A, aerogenes ATCC 8308 and their L-Threonine Production. The figures indicated are the amount of L-threonine accumulated $(\mathrm{mg} / \mathrm{ml})$. 
of L-threonine production. Fifteen out of 19 triple auxotrophs produced more L-threonine than the parent strain, $\mathrm{KY} 8274\left(\mathrm{DAP}^{-}, \mathrm{Met}^{-}\right)$.

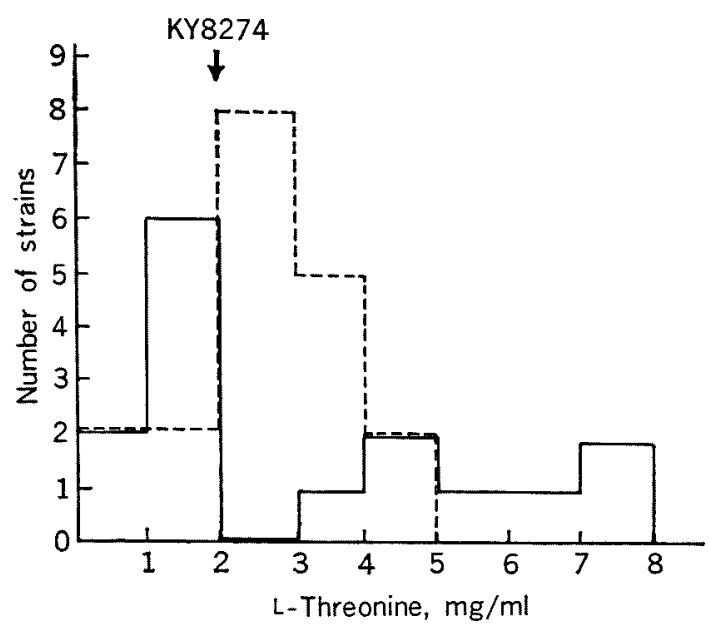

FIG. 2. Distribution of Triple Auxotrophs Derived from KY8274 and their Revertants with Respect to thier L-Threonine Production.

-.- Triple auxotrophs

- Revertants

The auxotrophs were cultured in $10 \mathrm{ml}$ of medium B supplemented with methionine, isoleucine and D.P in a large test tube for $72 \mathrm{hr}$ at $30^{\circ} \mathrm{C}$.
E. coli W ATCC 9637

L-Threonine $\mathrm{mg} / \mathrm{ml}$

0

KY8270 Met $^{-}$

KY8274 Met-, DAP-

$\mathrm{UV}$

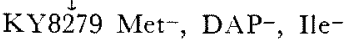

Spontaneous

KY8280 Met-, DAP-, Ilet $^{-}$

FIG. 3. Auxotrophs Derived from E. coli W ATCG 9637 and their L-Threonine Production.

Among the revertants, some were proved to be superior to their parent triple auxotrophs with respect to L-threonine productivity. As shown in Fig. 3, an isoleucine revertant, KY 8280 , produced L-threonine about twice (5 $\mathrm{mg} / \mathrm{ml}$ ) as much as the parent strain, KY8279 $\left(\mathrm{Met}^{-}, \mathrm{DAP}^{-}, \mathrm{Ile}^{-}\right)$.

\section{L-Threonine production by E. coli KY8280}

Some cultural conditions for L-threonine production by $E$. coli KY8280 were investigated.

The effect of DAP, methionine and isoleucine on threonine production is shown in Fig. 4.

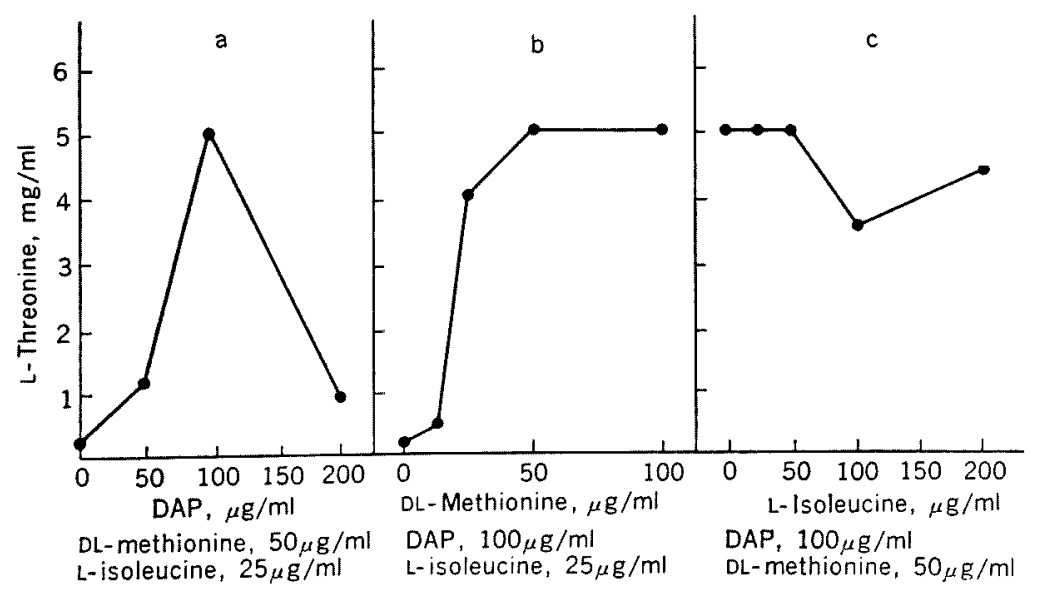

FIG. 4. Effect of DAP, Methionine and Isoleucine on L-Threonine Production in E. coli KY8280.

Medium B was supplemented with the indicated concentrations of DAP, methionine and isoleucine. Strain KY8280 was cultured in $10 \mathrm{ml}$ of the media in large test tubes for $72 \mathrm{hr}$ at $30^{\circ} \mathrm{C}$. 
Optimal level of DAP for L-threonine production was $100 \mu \mathrm{g} / \mathrm{ml}$ and high level of DAP $(200 \mu \mathrm{g} / \mathrm{ml})$ repressed L-threonine production (Fig. 4-a). DL-Methionine gave a good result at a level within $25 \sim 100 \mu \mathrm{g} / \mathrm{ml}$ (Fig. 4-b). Lower levels of L-isoleucine were favourable to threonine production as compared to its higher levels (Fig. 4-c).

Various carbon sources were tested for their effect on L-threonine production, and the results are presented in Table $\mathrm{V}$. Fructose gave the best results $(6.3 \mathrm{mg} / \mathrm{ml})$. With glycerol, mannitol, sorbitol and sucrose, L-threonine accumulation was moderately good. Besides, L-threonine was proved to be accumulated from acetic acid.

In order to increase the L-threonine production from fructose still further, the effect of its feeding during fermentation was investigated. As shown in Table VI, L-threonine production was not affected very much by fructose feeding, while it reached to a level of $11.2 \mathrm{mg} / \mathrm{ml}$ by prolonging the incubation time to 4 days without feeding.

An example of the chemical changes oc-

Table V. EFfect of Carbon Source on L-Threonine Production IN E. coli KY 8280

Glycerol in medium B was substituted by the indicated carbon sources, to which DL-methionine, DAP and isoleucine was supplemented at the concentration of $50 \mu \mathrm{g} / \mathrm{ml}, 100 \mu \mathrm{g} / \mathrm{ml}$ and $25 \mu \mathrm{g} / \mathrm{ml} \mathrm{re-}$ spectively. Strain KY8280 was cultured in $10 \mathrm{ml}$ of these media in large test tubes for $72 \mathrm{hr}$ at $30^{\circ} \mathrm{C}$.

\begin{tabular}{lccc}
\multicolumn{1}{c}{ C-Source } & $\mathrm{pH}$ & $\begin{array}{c}\mathrm{DCW} \text { (1) } \\
\mathrm{mg} / \mathrm{ml}\end{array}$ & $\begin{array}{c}\text { L-Threonine } \\
\mathrm{mg} / \mathrm{ml}\end{array}$ \\
\hline Glycerol & 6.4 & 4.6 & 4.0 \\
Mannitol & 5.9 & 4.7 & 4.2 \\
Sorbitol & 6.3 & 3.8 & 3.5 \\
Glucose & 5.8 & 3.3 & 2.4 \\
Sucrose & 6.0 & 3.9 & 4.6 \\
Fructose & 6.0 & 3.6 & 6.3 \\
Xylose & 6.3 & 3.4 & 2.9 \\
Cane molasses & 6.5 & 8.5 & 2.8 \\
CH ${ }_{3}$ COOH & 7.4 & 0.4 & 0.3 \\
\hline
\end{tabular}

a) Dried cell weight.
Table VI. EFfect of Fructose Feeding on L-Threonine Production in $E$. coli KY 8280

Initial fructose level was 5\%. Strain KY8280 was cultured in $30 \mathrm{ml}$ of medium distributed in $250 \mathrm{ml}$ Erlenmeyer flask at $30^{\circ} \mathrm{C}$. Three $\mathrm{ml}$ of $30^{\circ}$; fructose solution was fed at indicated period.

\begin{tabular}{|c|c|c|c|c|c|c|}
\hline \multirow{2}{*}{$\begin{array}{l}\text { Fructose } \\
(30 \\
\text { feeding }\end{array}$} & \multicolumn{3}{|c|}{3 days } & \multicolumn{3}{|c|}{4 days } \\
\hline & $\mathrm{pH}$ & $\begin{array}{c}\mathrm{DCW} / \mathrm{l} \\
\mathrm{mg} / \mathrm{ml}\end{array}$ & $\begin{array}{r}\text { L-Thr } \\
\mathrm{mg} / \mathrm{ml}\end{array}$ & $\mathrm{pH}$ & $\begin{array}{c}\mathrm{DCW}^{a} ! \\
\mathrm{mg} / \mathrm{ml}\end{array}$ & $\begin{array}{l}\mathrm{L}-\mathrm{Thr} \\
\mathrm{mg} / \mathrm{ml}\end{array}$ \\
\hline- & 5.8 & 4.0 & 8.1 & 5.9 & 4.4 & 11.2 \\
\hline $24 \mathrm{hr}$ & 5.7 & 4.1 & 8.3 & 5.9 & 4.1 & 11.4 \\
\hline $48 \mathrm{hr}$ & 5.7 & 3.8 & 7.4 & 5.8 & 4.7 & 11.2 \\
\hline
\end{tabular}

a) Dried cell weight

curring during the fermentation in 5 liters jar fermentor containing 3 liters of $7.5 \%$ fructose medium is given in Fig. 5. Growth reached to a maximum titer in about $48 \mathrm{hr}$, after which the concentration of L-threonine increased rapidly with a concurrent consumption of fructose and reached to a level of $13.8 \mathrm{mg} / \mathrm{ml}$ in $120 \mathrm{hr}$.

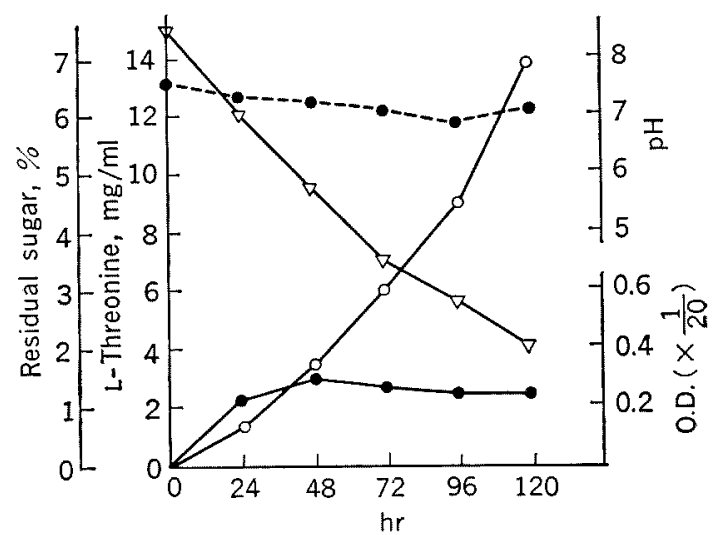

FIG. 5. Time Course of L-Threonine Fermentation in $E$. coli KY8280.

Cultivation was carried out in 5 liters jar fermentor containing 3 liters of $7.5 \%$ fructose medium.

The impeller speed was $550 \mathrm{rpm}$, and air was supplied at 3 liter $/ \mathrm{min}$.

$\mathrm{O}-\mathrm{O}$ L-Threonine, $\Delta \rightarrow \Delta$ Residual sugar $\mathrm{pH}$, - Optical dencity (O.D.) at $660 \mathrm{~m} \mu$. 


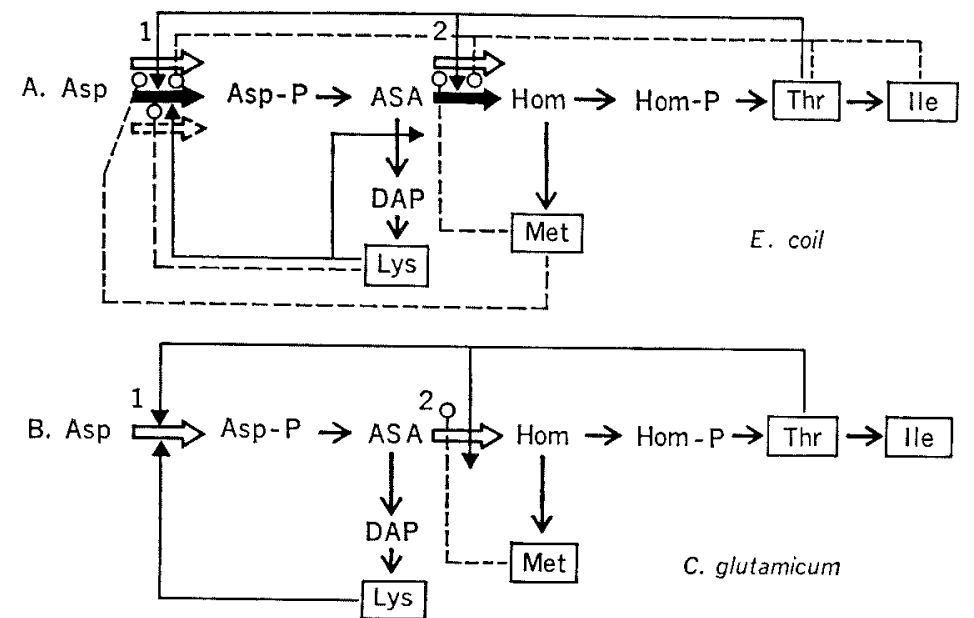

FIG. 6. Regulation of Threonine Biosynthesis in Escherichia coli and Corynebacterium glutamicum.

1. Aspartokinase 2, Homoserine dehydrogenase.

$\longrightarrow$ feed back inhibition, -.-O repression.

\section{DISCUSSION}

Fifteen strains of bacteria representing seven families were mutagenized to derive auxotrophs of amino acids directly related to threonine biosynthesis, i.e., methionine, isoleucine, lysine, and DAP. Among the isolated auxotrophs, those which produced an appreciable amount of L-threonine were found in $A$. aerogenes, $S$. marcescens and $E$. coli, all of which belong to the family Enterobacteriaceae. These results suggested that different systems of metabolic control in L-threonine biosynthesis might exist among different groups of bacteria. As a matter of fact, completely different control systems have been described with respect to threonine biosynthetic pathway. Figure 6 shows schematically this differences betwen $E$. coli $\mathrm{K} 12^{13 \sim 16)}$ and Corynebacterium

13) E. R. Stadtman, G. N. Cohen and G. LeBras, Ann. N.Y. Acad. Sci., 94, 9521 (1961).

14) E. R. Stadtman, G. N. Cohen, G. LeBras and H. deRobichon-Szulmajester, $J$. Biol. Chem., 236, 2033 (1961).

15) J. C. Patte, G. LeBras and G. N. Cohen, Biochim. Biophys. Acta, 136, 245 (1967).

16) J.C. Patte, G. LeBras, T. Loving and G. N. Cohen, ibid., 67, 16 (1963). glutamicum. ${ }^{17,18}$ In $E$. coli $\mathrm{K} 12,3$ aspartokinases and 2 homoserine dehydrogenases each of which are subject to independent end product control occur, while in C. glutamicum there appears to be a single aspartokinase subject to concerted feedback inhibition by lysine and threonine and a single homoserine dehydrogenase subject to end product control. From these findings, the differences of L-threonine production between $E$. coli and $C$. glutamicum might be reasonably explained as follows. In $E$. coli auxotrophs, even if the intracellular level of L-threonine should render threonine sensitive aspartokinase and homoserine dehydrogenase largely inoperative, other isofunctional enzymes should continue to synthesize L-threonine when other end products were limited. While, in C. glutamicum auxotrophs, inhibition of a single homoserine dehydrogenase by L-threonine might not be released by limiting any other end product level. Therefore, these auxotrophs must be unfavor-

17) K. Nakayama, H. Tanaka, H. Hagino and S. Kinoshita, Agr. Biol. Chem., 30, 611 (1966).

18) T. Nara, H. Samejima, C. Fujita, M. Ito, K. Nakayama and S. Kinoshita, ibid., 25, 532 (1961). 
able for L-threonine accumulation. The control mechanism found in $E$. coli $\mathrm{K} 12$ has been reported to be shared by the member of the family Enterobacteriaceae. ${ }^{19,201}$ While, in $B a$ cillus spp., ${ }^{21,221}$ Pseudomonas ${ }^{201}$ and Brevibacterium flavum, ${ }^{23)}$ the regulatory mechanism similar to that of C. glutamicum has been described. Thus it may be a reasonable result that auxotrophs accumulating a large amount of Lthreonine among various groups of bacteria were found in the family Enterobacteriaceae. In the latter groups of bacteria represented by C. glutamicum it seems to be rather essential

19) M. Freundlich and R. L. Cafferatta, J. Bacteriol., 97, 193 (1969).

20) G. N. Cohen, R. Y. Stanier and G. LeBras, ibid., 99, 791 (1969).

21) P. Datta and H. Gest, Nature, 203, 1959 (1964).

22) M. Paulus and F. Gray, J. Biol. Chem., 239, 4008 (1964).

23) R. Miyajima, S. Otsuka and I. Shiio, J. Biochem., 63, 139 (1968). for the production of a large amount of I threonine that homoserine dehydrogenase mu tates to be insensitive to the inhibition $b$ threonine, for example, like threonine analog resistant mutants. ${ }^{9,24}$

Huang $^{11}$ described L-threonine production by DAP and DAP plus methionine auxotroph of $E$. coli. However, it was difficult to rais the yield with these auxotrophs. Now, we have found that imposition of the third ad ditional requirement for isoleucine appreciably increased L-threonine accumulation. Besides some isoleucine revertants of these mutant: were proved to produce more threonine thar parent triple auxotrophs. The cause of the increase of L-threonine production in the re. vertans seems to be an interesting problem tc be explored.

24) I. Shiio, R. Miyajima and S. Nakamori, $J$. Biochem., 68, 859 (1970). 